\title{
Metallurgical Characterization of Hot Tearing Curves Recorded during Solidification of Magnesium Alloys
}

\author{
Y.D. Huang*, Z. Wang, A. Srinivasan, K.U. Kainer and N. Hort \\ Helmholtz-Zentrum Geesthacht, Institute of Materials Research \\ Max-Planck-Str. 1, D-21502 Geesthacht, Germany
}

\begin{abstract}
This work investigates the hot tearing behavior of $\mathrm{Mg}-\mathrm{Al}$ and $\mathrm{Mg}-\mathrm{Zn}$ alloys quantitatively based on the measurement of contraction force using an experimental setup which was developed at MagIC. An emphasis is given on the analysis of typical hot tearing curves to understand the corresponding metallurgical phenomena shown by these curves. The recorded hot tearing curves, i.e. the contraction force vs. temperature or time, contain valuable metallurgical information. They give not only the precise temperature at which the hot tearing initiates, but also depict information about the propagation of hot cracks. Combined with thermodynamic calculations, the critical solid fraction corresponding to the occurrence of hot tearing can be calculated. Further microstructural observations were performed. Several phenomena such as the crack propagation and refilling of cracks, which influence the slope of hot tearing curves, are also discussed.
\end{abstract}

PACS: 64.70.D-, 62.20.mt, 61.25.Mv, 61.66.Dk, 61.72.Mm

\section{Introduction}

Hot tearing (or hot cracking) is one of the most severe solidification defects commonly encountered during casting. It is such a complicated phenomenon that a full understanding is still not yet achieved, though it has been extensively investigated for decades. Most contributions are still based on qualitative characterizations $[1,2]$. Two experimental methods, i.e. constrained rod casting (CRC) and ring mould casting (RMC) are popularly employed. Either the total crack length/crack width, the critical rod length (in CRC test) or the critical ring diameter (in RMC test) at which no crack can be observed, are normally used as a qualitative assessment index for the hot tearing susceptibility [2]. Due to the fact that only the final crack length is normally used to evaluate the hot tearing susceptibility, and that the process during which the hot tearing is formed was not recorded, a lot of significant information cannot be obtained. This leads to the difficulties in deep analyzing the mechanisms for the formation of hot tearing. The lack of quantitative knowledge suggests a need for more fundamental experimental investigations on hot tearing, particularly on a quantitative basis.

Investigations on hot tearing are mainly focused on the steels and aluminum alloys. In contrast, only limited work had been done for magnesium alloys [3-7]. Moreover most of previous inspections were carried out only for $\mathrm{Mg}-\mathrm{Al}$ series. They surveyed the effect of alloying

\footnotetext{
* corresponding author; e-mail: yuanding.huang@hzg.de
}

elements such as $\mathrm{Ca}$, $\mathrm{Sr}$ and $\mathrm{RE}$ on the hot tearing susceptibility of $\mathrm{Mg}-\mathrm{Al}$ alloys $[4,5,8]$. Recently, the hot tearing of $\mathrm{Mg}-\mathrm{Zn}$ alloys was also investigated. It is found that $\mathrm{Mg}-\mathrm{Zn}$ system has the largest hot tearing susceptibility at the content of $1.5 \mathrm{wt} \% \mathrm{Zn}$ [7]. The present work used a novel quantitative system to investigate the hot tearing of $\mathrm{Mg}-\mathrm{Al}$ and $\mathrm{Mg}-\mathrm{Zn}$ alloys. The evolution of contraction force was recorded during solidification process so that the formation process of hot tearing can be inspected.

\section{Experimental}

To detect the initiation of the hot tearing, a system based on the measurement of contraction force was developed [6, 7]. The system consists of a constrained rod casting mould, a contraction force measurement system with a load cell, a data logging unit and a data recording program. A similar design can be found in the works by Wang et al. [9] and Cao et al. [10]. However, the advantage of the present evaluation system, which is mainly different from Wang and Cao's apparatus, is to eliminate the influence of friction between the mould wall and casting rod. The details of the apparatus were given elsewhere $[6,11,12]$.

A cylindrical mild steel crucible coated with BN was used for melting $\mathrm{Mg}-\mathrm{Al}$ and $\mathrm{Mg}-\mathrm{Zn}$ alloys in an electrical resistance furnace. High purity $\mathrm{Ar}+0.2 \% \mathrm{SF}_{6}$ mixed protective gas was used for melt protection. Pure magnesium (99.9 wt\%), aluminium (99.9 wt\%) and zinc (99.6 wt\%) were used as starting materials. They were heated and melted at $700^{\circ} \mathrm{C}$. The melt was stirred for 
5 min manually. Then the melt was held at the pouring temperature for about $5 \mathrm{~min}$ before casting. The pouring temperature was set at $80^{\circ} \mathrm{C}$ above the liquidus temperature. The melt was poured into a mould coated with a thin layer of $\mathrm{BN}$, which was preheated to a temperature between $250^{\circ} \mathrm{C}$ and $500^{\circ} \mathrm{C}$. Once the solidification started the measurement system of force was activated. The force induced by shrinkage and thermal contraction during cooling was recorded through the load cell. Temperature was recorded by thermocouples located at different positions inside the melt near the sprue-rod junction and along the rod within the mould [11]. The temperatures used for plotting hot tearing curves were taken from the measured values near the location of sprue-rod junctions, which is close to the site where the cracks could be initiated.

\section{Results and discussion}

Figure 1 shows the typical hot tearing curves recorded during solidification of $\mathrm{Mg}-1 \mathrm{Al}$ alloy with different mould temperatures. Based on these curves, i.e. the contraction force and temperature as a function of time, a lot of quantitative and qualitative information can be obtained, such as the initiation of hot tearing, its propagation and healing during solidification.

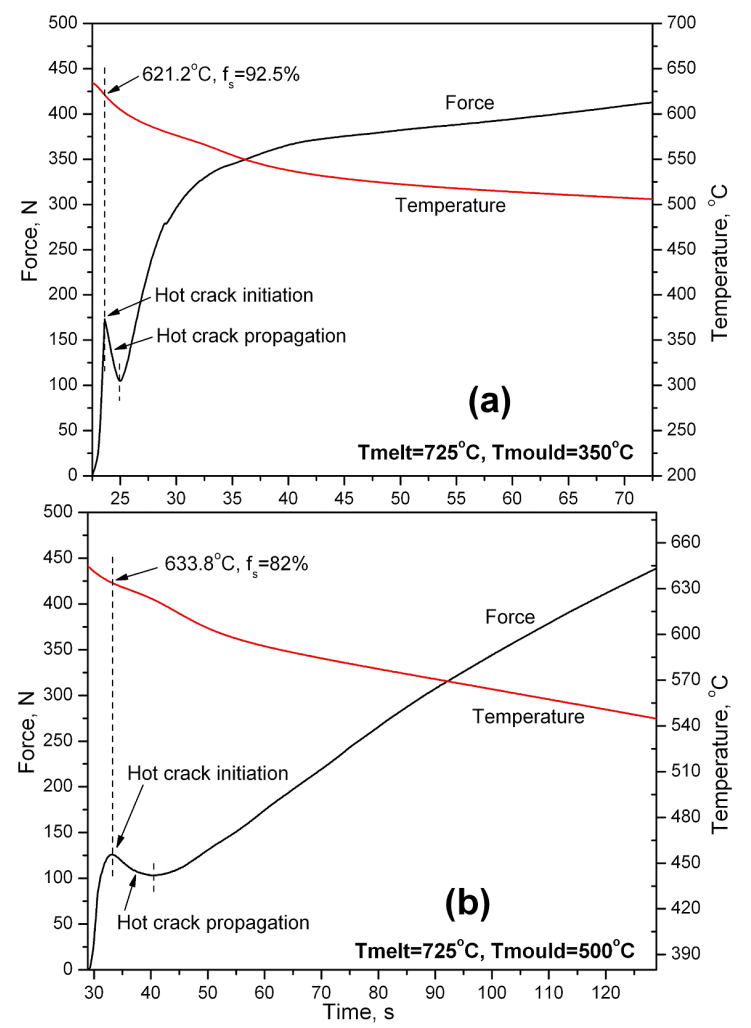

Fig. 1. Contraction force and temperature as a function of time for $\mathrm{Mg}-1 \mathrm{wt} \% \mathrm{Al}$ alloy cast at $725^{\circ} \mathrm{C}$ with the mould temperature of (a) $350{ }^{\circ} \mathrm{C}$ and (b) $500{ }^{\circ} \mathrm{C}$.

\subsection{Initiation of hot tearing}

When the solidification starts, the contraction force quickly increases, reaches to a maximum and then decreases for a while before it increases again (Fig. 1). This means that when the temperature drops to $621.2^{\circ} \mathrm{C}$ the force relaxation occurs due to the formation of hot tears in $\mathrm{Mg}-1 \mathrm{Al}$ alloy with mould temperature $350^{\circ} \mathrm{C}$. The position of this peak can be regarded as the initiation of hot tears. Based on the corresponding solidification temperature to this peak position, the solid fraction can be calculated using thermodynamic calculation. For $\mathrm{Mg}-1 \mathrm{Al}$ alloy with mould temperature $350^{\circ} \mathrm{C}$, the hot tears are formed at a solid fraction of about 0.925 , which is in agreement with the well established knowledge that hot tearing normally occurs at the latest stage of solidification when an approximate $5 \%$ liquid is left [1]. As shown in Fig. 1, the initiation temperature of hot tearing is influenced by the mould temperature. With the mould temperature increasing to $500^{\circ} \mathrm{C}$, the onset temperature (i.e. the peak position) increases to $633.8^{\circ} \mathrm{C}$. This corresponds to a solid fraction of only 0.82 .

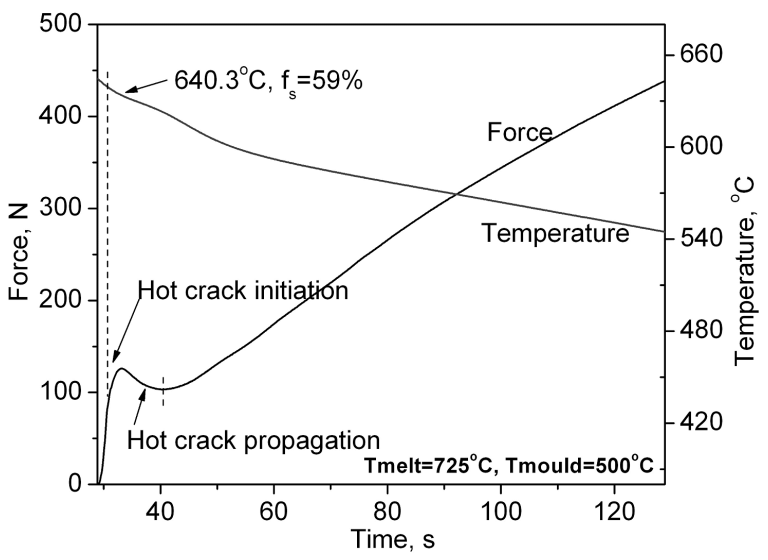

Fig. 2. Contraction force and temperature as a function of time for $\mathrm{Mg}-1 \mathrm{wt} \% \mathrm{Al}$ alloy cast at $725^{\circ} \mathrm{C}$ with the mould temperature of $500{ }^{\circ} \mathrm{C}$.

Like the case observed for $\mathrm{Mg}-1 \mathrm{Al}$ alloy with mould temperature $500{ }^{\circ} \mathrm{C}$ (Fig. 1b), it is not so reasonable to regard the peak position as the initiation of hot tears. Careful examination of the load curves in Fig. 1a and b shows that these two peak shapes are quite different. The former is sharp and the rate of load change before reaching the peak load is linear. The latter is blunt and a nonlinear relationship is observed before reaching its maximum. It is much reasonable to consider the point (Fig. 2), at which the relationship between the contraction force and time changes from linear to nonlinear, as the initiation of hot tears. At this point, the change in the slope of contraction force vs. time should be caused by the initiation of hot tears which lead to the partial relaxation of thermal stress. The corresponding temperature and solid fraction are then corrected with a value of $640.3^{\circ} \mathrm{C}$ and 0.59 , respectively. 


\subsection{Propagation of hot tears}

Once the hot tears are initiated, the increment in the contraction force becomes slow or it decreases with the proceeding of solidification (Fig. 1, Fig. 2, and Fig. 3). The duration from the initiation of hot tears to the lowest point in the load curve where the force is lowest is the stage of hot tear propagation. Their propagation rate can be determined from the slope of curves. They depend both on the alloy composition and on the mould temperature. For $\mathrm{Mg}-1 \mathrm{Al}$ alloy with mould temperature of $350^{\circ} \mathrm{C}$ (Fig. 1a) and $\mathrm{Mg}-1 \mathrm{Zn}$ alloy with mould temperature of $300{ }^{\circ} \mathrm{C}$ (Fig. 3a), the contraction force drops sharply and almost linearly reduces after the hot tears are initiated. This means that in these two alloys the hot tears propagate very quickly. In contrast, when the mould temperature increases, i.e. the cooling rate reduces, the propagation rate of hot tears decreases (Fig. 1a). In addition, when the alloy composition is changed, the propagation of cracks also correspondingly changes. For example, the content of $\mathrm{Zn}$ increases from $1 \mathrm{wt} \%$ to $12 \mathrm{wt} \%$, the crack propagation becomes very slow (Fig. $3 \mathrm{~b}$ ).

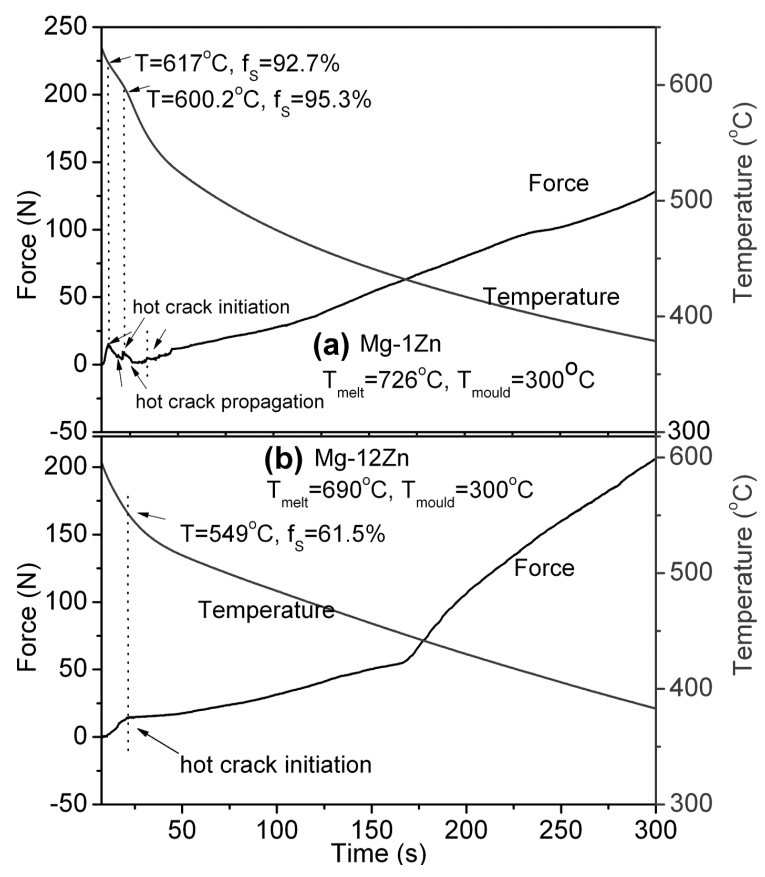

Fig. 3. Typical curves of contraction force as a function of solidification time, (a) $\mathrm{Mg}-1 \mathrm{Zn}$, mould temperature $300^{\circ} \mathrm{C}$ and (b) $\mathrm{Mg}-12 \mathrm{Zn}$, mould temperature $300{ }^{\circ} \mathrm{C}$.

Microstructural observations indicate that the hot tears normally propagate along the dendritic or grain boundaries. Figure 4 shows the morphologies of hot tear surfaces for $\mathrm{Mg}-\mathrm{Zn}$ alloys prepared under the same mould temperature. For $\mathrm{Mg}-1 \mathrm{wt} \% \mathrm{Zn}$ alloy, the surface of hot tear is very smooth with some evidence of fractured grain bridges, indicating that there is almost no liquid refilling to the crack. Different from the $\mathrm{Mg}-1 \mathrm{wt} \% \mathrm{Zn}$ alloy, the surfaces of hot tears are not smooth any more in $\mathrm{Mg}-12$ wt\% $\mathrm{Zn}$ alloy. In some areas, a thin layer of material is observed on the fracture surface with a river flow pattern. The energy dispersive analysis (EDX) result indicates a much higher Zn content in these layers, which corresponds to the eutectic composition, indicating the existence of refilled liquid on the surface of crack. These microstructural observations may explain why the hot tears propagate much more quickly in $\mathrm{Mg}-1 \mathrm{wt} \% \mathrm{Zn}$ alloy than in $\mathrm{Mg}-12 \mathrm{wt} \% \mathrm{Zn}$ alloy (Fig. 3).

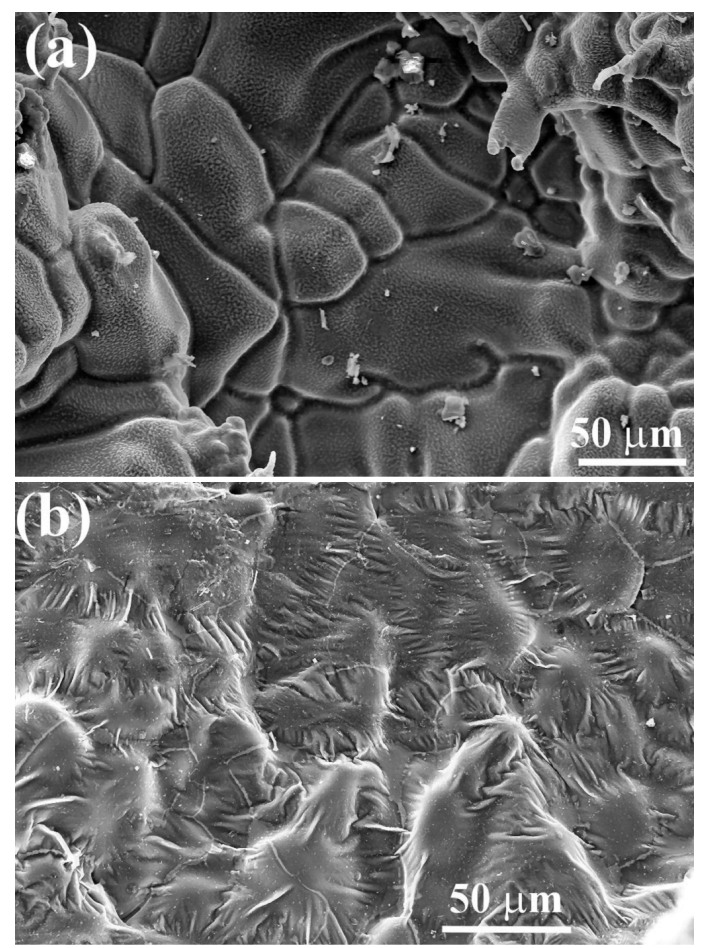

Fig. 4. Morphologies of hot crack surfaces, mould temperature $300^{\circ} \mathrm{C}$, (a) $\mathrm{Mg}-1 \mathrm{Zn}$ and (b) $\mathrm{Mg}-12 \mathrm{Zn}$.

Figure 3a shows another interesting metallurgical phenomenon occurred during solidification. The serrated peaks are observed at the early stage of solidification on the hot tearing curve, indicating that the hot tears are easy to be initiated and propagate in $\mathrm{Mg}-1 \mathrm{Zn}$ alloy with mould temperature $300^{\circ} \mathrm{C}$. This interesting result is in agreement with that obtained by microstructural observations (Fig. 4a).

\subsection{Healing of hot tears}

As mentioned above, after the initiation of hot tears, the contraction force drops in linear model or sometimes in nonlinear model with solidification proceeding. One explanation for this difference is that the initiated crack had been partially or completely healed, by the refilling of the remaining liquid. The refilling of the remaining liquid slows down the propagation of the hot tears. Under this situation, the contraction force reduces in a nonlinear way as observed in $\mathrm{Mg}-1 \mathrm{Al}$ alloy with mould temperature $500{ }^{\circ} \mathrm{C}$ (Fig. 1b), or no apparent drop of contraction 
force as seen in $\mathrm{Mg}-12 \mathrm{Zn}$ with mould temperature $300^{\circ} \mathrm{C}$ (Fig. 3b). In $\mathrm{Mg}-12 \mathrm{Zn}$ with mould temperature $300^{\circ} \mathrm{C}$, the amount of low temperature eutectic phases is high and the fluidity of liquid is improved at the later stage of solidification. Thus this sample has a better refilling ability. The more eutectic liquid is present, the more likely the solidifying alloy can accommodate the rising tension and cracks can be healed [4]. Based on the microstructural observations, the hot tearing is largely influenced by the microstructural situation at the grain boundaries and the ability of refilling at the later stage of solidification.

When a new crack is formed during solidification, its subsequent propagation will locally generate negative pressure. This negative pressure drives the remaining liquid to fill the crack opening. When the liquid refills in the crack opening, the localized stress is largely decreased due to the surface tension of the liquid. As a result, the crack propagation is interrupted or even completely stopped. In this way, the crack can be healed. In the present work, with the higher mould temperature there is more liquid left at the onset temperature of the hot crack. Therefore, the possibility of crack refilling is high and hence the crack propagates more slowly compared to lower mould temperature.

\section{Conclusions}

The curves of contraction force as a function of time and temperature, which are recorded by the developed quantitative setup, contains a lot of information about the formation of hot tearing:

- The initiation temperature of hot tears can be determined based on these curves. If combined with the thermodynamic calculations, the corresponding critical solid fraction at which the hot tearing is initiated can be concluded.

- The propagation of hot tears can be tracked on these curves. The drop rate of contraction force after the initiation of hot tears reflects the propagation rate of hot tears.

- Based on the drop model of contraction force after the initiation of hot tears and the microstructure observations, whether the healing of hot tears occurs or not can be deduced, which proceeds by the refilling of remaining liquid.

\section{References}

[1] J. Campbell, Castings, Butterworth-Heinemann, Oxford 2003.

[2] D.G. Eskin Suyitno, L. Katgerman, Prog. Mater. Sci. 49, 629 (2004).

[3] G. Cao, I. Haygood, S. Kou, Metall. Mater. Trans. A 41, 2139 (2010).

[4] G. Cao, S. Kou, Metall. Mater. Trans. 37A, 3647 (2006).

[5] G. Cao, C. Zhang, H. Cao, Y.A. Chang, S. Kou, Metall. Mater. Trans. 41, 706 (2010).

[6] Z.S. Zhen, N. Hort, Y.D. Huang, O. Utke, N. Petri, K.U. Kainer, Int. J. Cast Met. Res. 22, 331 (2009).

[7] L. Zhou, Y.D. Huang, P.L. Mao, K.U. Kainer, Z. Liu, N. Hort, Int. J. Cast Met. Res. 24, 170 (2011).

[8] W. Zheng, S. Li, B. Tang, D. Zeng, X. Guo, J. Rare Earths 24, 346 (2006).

[9] Y.S. Wang, B.D. Sun, Q.D. Wang, Y.P. Zhu, W.J. Ding, Mater. Lett. 53, 35 (2002).

[10] G. Cao, S. Kou, in: Magnesium Technology 200\%, Eds. R.S. Beals, A.A. Luo, M.R. Neelameggham, M.O. Pekguleryuz, TMS, Orlando, FL 2007, p. 133.

[11] Z.S. Zhen, N. Hort, Y.D. Huang, N. Petri, O. Utke, K.U. Kainer, Mater. Sci. Forum 618-619, 533 (2009).

[12] Z.S. Zhen, N. Hort, O. Utke, Y.D. Huang, N. Petri, K.U. Kainer, in: Magnesium Technology 2009, Eds. E.A. Nyberg, S.R. Agnew, M.R. Neelameggham, M.O. Pekguleryuz, TMS, San Francisco, CA 2009, p. 105. 